\title{
Communication
}

\section{A Water Cluster Conduit in Crystal}

\author{
Fangfang Jian *, E Liu and Jiao Xu \\ School of Chemical Engineering and Pharmaceutics, Henan University of Science and Technology, \\ Luoyang 471023, China; 798233143@haust.edu.cn (E.L.); 18437960281@163.com (J.X.) \\ * Correspondence: ffj2013@163.com; Tel.: +86-138-0895-9914
}

Received: 25 October 2017; Accepted: 14 December 2017; Published: 20 December 2017

\begin{abstract}
The crystal structure of compound (1), $\left[\mathrm{CuCl}(\mathrm{phen})\left(\mathrm{H}_{2} \mathrm{NCH}_{2} \mathrm{COO}\right)\right] \cdot 4 \mathrm{H}_{2} \mathrm{O}$, reveals an unusual hydrogen-bond water cluster aggregate T6(2)6(2). Four water molecules in (1) form an isolated water cluster, $\left[\left(\mathrm{H}_{2} \mathrm{O}\right)_{14}\right]_{n}$, resembling a "phenanthro-[1,2]phenanthrene polymer structure shape" along the ac plane. The two face-face parallel $\left[\left(\mathrm{H}_{2} \mathrm{O}\right)_{14}\right]_{n}$ planes are bridged by $\mathrm{Cl}$ atoms in [CuCl(phen) $\left.\left(\mathrm{H}_{2} \mathrm{NCH}_{2} \mathrm{COO}\right)\right]$ with a strong $\mathrm{O}-\mathrm{H} \cdots \mathrm{Cl}$ hydrogen bond to form a water cluster conduit.
\end{abstract}

Keywords: glycine; water cluster; nanometer sized; crystal; hydrogen-bond

\section{Introduction}

Water is the most abundant compound on Earth, and is very difficult to eliminate from other solvents (even when there is no water in the synthesis steps). Furthermore, it is not present in the solvents used for crystallization where hydrates can be obtained. The presence of water molecules in any crystal structure can play an important role in stabilizing some supramolecular species, as the number of hydrogen bond acceptors and donors can differ from those of anhydrous compounds [1,2]. Structural studies on discrete water clusters within the lattice of a crystal host have significantly advanced our understanding of the behavior of bulk water [3-6]. Elucidating the assembly of discrete water aggregates, and understanding how water aggregates interact with a crystal host, are still challenging scientific endeavors [7-13]. A number of water oligomers have been extensively studied using X-ray diffraction methods [14-24]. The aggregation of lattice water molecules in crystals, into hydrogen-bonded clusters as well as infinite networks, has generated considerable interest [25-34]. Infantes et al. [35,36] examined about 1400 hydrated structures, retrieved from the Cambridge Structural Database (CSD), and performed classifications of water/water motifs, using statistics regarding their relative frequencies. The established classification system is as follows: $\mathrm{D}$ (discrete chain), R (discrete rings), C (infinite chains), $\mathrm{T}$ (infinite tapes), and L (infinite layers). In Reference [37], a proper analysis was lacking, which should be done when reporting any new water morphologies in a crystal lattice. With this in mind, and with the help of the Cambridge Crystallographic Data Centre (CCDC), we performed a Cambridge Structural Database (CSD) search for the phenanthrene structure-shaped motif with 14 water molecules, of which the aggregate is T6(2)6(2). We did not find any phenanthrene structure-shaped patterns in CCDC. Therefore, there is presently no structural information available for a discrete, phenanthrene structure-shaped $\left(\mathrm{H}_{2} \mathrm{O}\right)_{14}$ cluster, nor for its participation in the stabilization of a suramolecular assembly. In this paper, we report on an unusual hydrogen-bond water cluster, $\left[\left(\mathrm{H}_{2} \mathrm{O}\right)_{14}\right]_{n}$, which can form nanometer-sized water cluster conduits (with a diameter of about $12.034 \AA$ ) using a strong $\mathrm{O}-\mathrm{H} \cdots \mathrm{Cl}$ hydrogen bond.

\section{Results}

$\mathrm{CuCl}_{2} \cdot 2 \mathrm{H}_{2} \mathrm{O}(1.70 \mathrm{~g}, 0.01 \mathrm{~mol})$ was added to a heat solution $\left(80 \sim 90^{\circ} \mathrm{C}\right)$ of glycine $\left(\mathrm{H}_{2} \mathrm{NCH}_{2} \mathrm{COOH}\right)$ $(0.75 \mathrm{~g}, 0.01 \mathrm{~mol})$ and $\mathrm{NaOH}(0.40 \mathrm{~g}, 0.01 \mathrm{~mol})$ in $40 \mathrm{~mL}$ of water. The reaction mixture was stirred at about $90{ }^{\circ} \mathrm{C}$ for $10 \mathrm{~min}$. Then phenanthroline $(3.55 \mathrm{~g}, 0.02 \mathrm{~mol})$ was added, and the solution was stirred 
for another $4 \sim 5 \mathrm{~h}$ at about $90^{\circ} \mathrm{C}$. After filtering out the precipitate, the resulting solution was left to stand undisturbed. Upon slow evaporation at room temperature, blue crystals were obtained from the mother liquor. They were all collected, dried, and submitted for elemental analysis. The compound (1) was achieved with a yield of $75 \%$. The single crystals X-ray confirmed that the blue crystal was $\left[\mathrm{CuCl}(\right.$ phen $\left.)\left(\mathrm{H}_{2} \mathrm{NCH}_{2} \mathrm{COO}\right)\right] \cdot 4 \mathrm{H}_{2} \mathrm{O}(\mathbf{1})$. The elemental analysis supports this formulation.

Figure 1 shows the hydrogen bond interaction between $\left[\mathrm{CuCl}(\mathrm{phen})\left(\mathrm{H}_{2} \mathrm{NCH}_{2} \mathrm{COO}\right)\right]$ and the water cluster $\left[\left(\mathrm{H}_{2} \mathrm{O}\right)_{14}\right]_{n}$, and view of the water-chloride T12(3) aggregate. Figure 2 shows the nanometer-sized water cluster conduit. Tables 1 and 2 list the hydrogen bonds and $\pi-\pi$ interactions, respectively.
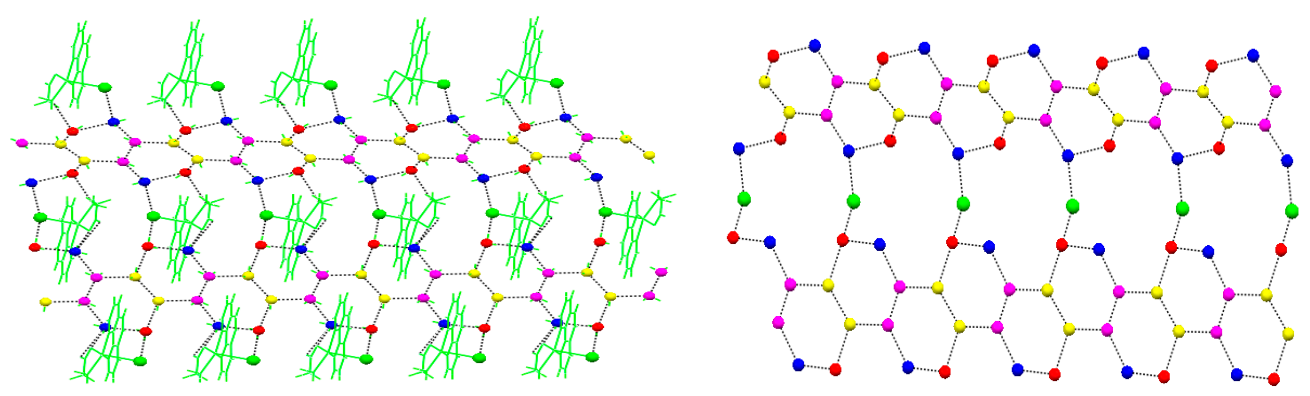

Figure 1. (Left) Depicting the hydrogen bond interaction of $\left[\mathrm{CuCl}(\mathrm{phen})\left(\mathrm{H}_{2} \mathrm{NCH}_{2} \mathrm{COO}\right)\right]$ with the water cluster; (Right) View of the water-chloride T12(3) aggregate. The water clusters and $\mathrm{Cl}$ atoms are depicted as a ball and stick model for clarity. Colors are as follows: blue, O1w; red, O2w; pink, O3w; yellow, $\mathrm{O} 4 \mathrm{w}$; black dashed, hydrogen bond; green and capped stick, $\left[\mathrm{CuCl}(\mathrm{phen})\left(\mathrm{H}_{2} \mathrm{NCH}_{2} \mathrm{COO}\right)\right]$ group and hydrogen atom.
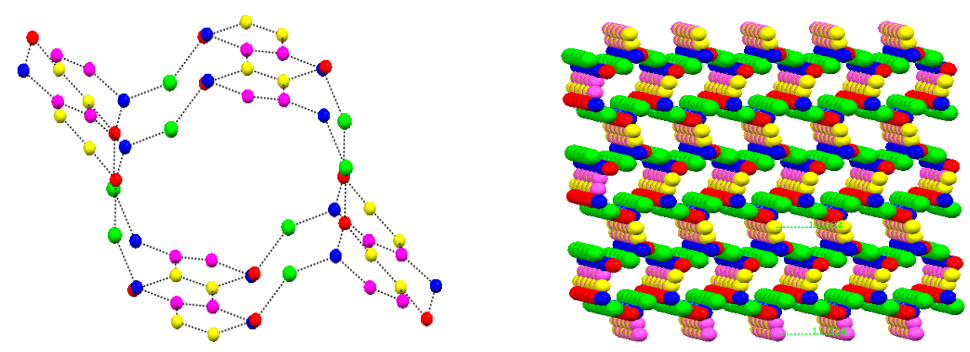

Figure 2. (Left) The formation of the water cluster cavity; (Right) View of the nanometer-sized water cluster conduit in the $a$ axis. The $\mathrm{Cl}$ atoms are detained and $\left[\mathrm{CuCl}\right.$ (phen) $\left.\left(\mathrm{H}_{2} \mathrm{NCH}_{2} \mathrm{COO}\right)\right]$ is omitted for clarity. Colors are as follows: blue, $\mathrm{O} 1 \mathrm{w}$; red, O2w; pink, $\mathrm{O} 3 \mathrm{w}$; yellow, $\mathrm{O} 4 \mathrm{w}$; Green, $\mathrm{Cl}$ atom.

Table 1. Geometrical parameters of hydrogen bonds $(\AA, \mathrm{deg})$ for the water cluster.

\begin{tabular}{|c|c|c|c|}
\hline \multicolumn{2}{|c|}{ Length } & \multicolumn{2}{|l|}{ Angle } \\
\hline O1w-O1 & $2.920(1)$ & $\mathrm{O} 2 \mathrm{w}^{\mathrm{F}} \ldots \mathrm{O} 1 \mathrm{w} \ldots \mathrm{O} 3 \mathrm{w}^{\mathrm{C}}$ & 114.39 \\
\hline $\mathrm{O} 1 \mathrm{w}-\mathrm{O} 2$ & $3.005(1)$ & $\mathrm{O} 2 \mathrm{w}^{\mathrm{F}} \ldots \mathrm{O} 1 \mathrm{w} \ldots \mathrm{O} 1$ & 84.88 \\
\hline $\mathrm{O} 1 \mathrm{w}-\mathrm{Cl}(1)^{\mathrm{A}}$ & $3.080(2)$ & $\mathrm{O}_{2} \mathrm{w}^{\mathrm{F}} \ldots \mathrm{O} 1 \mathrm{w} \ldots \mathrm{O} 2$ & 109.56 \\
\hline $\mathrm{O} 1 \mathrm{w}-\mathrm{O} 3 \mathrm{w} \mathrm{C}$ & $2.757(1)$ & $\mathrm{O} 2 \mathrm{w}^{\mathrm{F}} \ldots \mathrm{O} 1 \mathrm{w} \ldots \mathrm{Cl}(1)^{\mathrm{A}}$ & 99.34 \\
\hline $\mathrm{O} 2 \mathrm{w}-\mathrm{O} 1 \mathrm{w}^{\mathrm{B}}$ & $2.743(1)$ & $\mathrm{O} 3{ }_{\mathrm{w}} \mathrm{C} \ldots \mathrm{O} 1 \mathrm{w} \ldots \mathrm{O} 1$ & 96.28 \\
\hline $\mathrm{O} 2 \mathrm{w}-\mathrm{O} 4 \mathrm{w} \mathrm{C}$ & $2.754(1)$ & $\mathrm{O} 3 w^{C} \ldots \mathrm{O} 1 \mathrm{w} \ldots \mathrm{O} 2$ & 115.53 \\
\hline $\mathrm{N} 3-\mathrm{O} 2{ }_{\mathrm{w}} \mathrm{C}$ & 3.043 & $\mathrm{O} 3 w^{\mathrm{C}} \ldots \mathrm{O} 1 \mathrm{w} \ldots \mathrm{Cl}(1)^{\mathrm{A}}$ & 126.05 \\
\hline $\mathrm{O} 2 \mathrm{w}^{\mathrm{B}}-\mathrm{Cl}(1)$ & $3.223(1)$ & $\mathrm{O}_{1} \mathrm{w}^{\mathrm{B}} \ldots \mathrm{O} 2 \mathrm{w} \ldots \mathrm{O} 4 \mathrm{w}^{\mathrm{C}}$ & 98.83 \\
\hline $\mathrm{O} 3 \mathrm{w}-\mathrm{O} 4 \mathrm{w}$ & $2.403(1)$ & $\mathrm{O} 1 \mathrm{w}^{\mathrm{B}} \ldots \mathrm{O} 2 \mathrm{w} \ldots \mathrm{N}^{\mathrm{C}}$ & 94.22 \\
\hline $\mathrm{O} 3 \mathrm{w}-\mathrm{O} 3 \mathrm{w}^{\mathrm{D}}$ & $2.412(1)$ & $\mathrm{O}_{1} w^{\mathrm{B}} \ldots \mathrm{O} 2 \mathrm{w} \ldots \mathrm{Cl}(1)^{\mathrm{B}}$ & 103.79 \\
\hline $\mathrm{O} 4 \mathrm{w}-\mathrm{O} 4 \mathrm{w}^{\mathrm{E}}$ & $2.608(1)$ & $\mathrm{O} 4 \mathrm{w}^{\mathrm{C}} \ldots \mathrm{O} 2 \mathrm{w} \ldots \mathrm{N} 3^{\mathrm{C}}$ & 91.39 \\
\hline
\end{tabular}


Table 2. $\pi-\pi$ interactions (face-to-face) in complex (1) ${ }^{\mathrm{a}}$.

\begin{tabular}{|c|c|c|c|}
\hline $\operatorname{Ring}(i) \rightarrow \operatorname{Ring}(j) / C$ & $\begin{array}{l}\text { Distance between the } \\
(i, j) \text { Ring Centroids ( }(\AA)\end{array}$ & $\begin{array}{c}\text { Dihedral Angle }(i, j) \\
\text { (Deg) }\end{array}$ & $\begin{array}{l}\text { Distance of Centroid (i) } \\
\text { from Ring }(j)(\AA)\end{array}$ \\
\hline $\mathrm{R} 1 \rightarrow \mathrm{R} 4^{\mathrm{i}}$ & 3.528 & 0.67 & 3.354 \\
\hline $\mathrm{R} 2 \rightarrow \mathrm{R} 3$ & 3.618 & 2.10 & 3.379 \\
\hline $\mathrm{R} 2 \rightarrow \mathrm{R} 4{ }^{\mathrm{ii}}$ & 3.844 & 0.92 & 3.372 \\
\hline $\mathrm{R} 2 \rightarrow \mathrm{R} 4^{\mathrm{i}}$ & 3.588 & 0.92 & 3.379 \\
\hline $\mathrm{R} 4 \rightarrow \mathrm{R} 4{ }^{\mathrm{ii}}$ & 3.528 & 0.67 & 3.389 \\
\hline $\mathrm{R} 4 \rightarrow \mathrm{R} 4^{\mathrm{i}}$ & 3.865 & 0.00 & 3.389 \\
\hline
\end{tabular}

a Symmetry code: (i) $=-x, 1-y, 1-z$; (ii) $=1-x, 1-y, 1-z$. $\mathrm{R}(i) / \mathrm{R}(j)$ denotes the $i$ th $/ j$ th rings of phen: $\mathrm{R}(1)=$ $\mathrm{Cu}(1) / \mathrm{N}(1) / \mathrm{C}(12) / \mathrm{C}(11) / \mathrm{N}(2) ; \mathrm{R}(2)=\mathrm{N}(1) / \mathrm{C}(1) / \mathrm{C}(2) / \mathrm{C}(3) / \mathrm{C}(4) / \mathrm{C}(12) ; \mathrm{R}(3)=\mathrm{N}(2) / \mathrm{C}(10) / \mathrm{C}(9) / \mathrm{C}(8) / \mathrm{C}(7) / \mathrm{C}(11) ;$ $\mathrm{R}(4)=\mathrm{C}(4) / \mathrm{C}(5) / \mathrm{C}(6) / \mathrm{C}(7) / \mathrm{C}(11) / \mathrm{C}(12)$.

\section{Discussion}

The compound (1) contains one $\left[\mathrm{CuCl}(\mathrm{phen})\left(\mathrm{H}_{2} \mathrm{NCH}_{2} \mathrm{COO}\right)\right]$ and four water molecules. There is no obvious bonding interaction between the $\left[\mathrm{CuCl}(\mathrm{phen})\left(\mathrm{H}_{2} \mathrm{NCH}_{2} \mathrm{COO}\right)\right]$ groups with the shortest distance of $\mathrm{Cu} \cdots \mathrm{Cu}$ 7.010(1) $\AA$ (Figure 1, left). The coordination environments of each $\mathrm{Cu}$ (II) atom is pentacoordinated with three $\mathrm{N}$ atoms from phenanthroline ligands and $\mathrm{NH}_{2}$ of glycine, one $\mathrm{O}$ atom from carboxy of glycine, and one $\mathrm{Cl}$ atom in a distorted square pyramidal geometry. Three nitrogen atoms and one oxygen atom occupy the basal sites with Cu-N distances of 2.000(5) 2.028(5) $\AA$ and $\mathrm{Cu}-\mathrm{O}$ distances of 1.950(4) $\AA$. The coordinated chloride occupies the apical position with $\mathrm{Cu}(1)-\mathrm{Cl}(1)$ distances of 2.577(2) $\AA$. The bite angle of chelating glycine and phenanthroline ligands $\mathrm{O}(1)-\mathrm{Cu}(1)-\mathrm{N}(3)$ and $\mathrm{N}(1)-\mathrm{Cu}(1)-\mathrm{N}(2)$ is $83.8(2)^{\circ}$ and $81.9(2)^{\circ}$, respectively. The $\mathrm{Cu}$ atom with the phenanthroline ligand are quite planar, and the maximum atom deviation from the least squares plane is $0.039(3) \AA$. The glycine ligand with the $\mathrm{Cu}$ atom is nearly planar, with the largest deviation of $0.203(1) \AA$ for $\mathrm{O}(2)$. The dihedral angle between the glycine moiety and phenanthroline group is $11.58^{\circ}$. In the crystal building, the $\left[\mathrm{CuCl}\right.$ (phen) $\left.\left(\mathrm{H}_{2} \mathrm{NCH}_{2} \mathrm{COO}\right)\right]$ is held together by means of face-to-face $\pi-\pi$ interactions among the aromatic phenanthroline ligands and a glycine $\mathrm{Cu}$ five-membered chelating ring to form layers parallel to the ac plane.

It is especially interesting to note that four water molecules in compound (1) form a water cluster, $\left[\left(\mathrm{H}_{2} \mathrm{O}\right)_{14}\right]_{n}$. To best our knowledge, this T6(2)6(2) aggregate represents a new water cluster structure, which has not been reported before [35-37]. The water cluster $\left[\left(\mathrm{H}_{2} \mathrm{O}\right)_{14}\right]_{n}$ units are strongly held together by $\mathrm{O}-\mathrm{H} \cdots \mathrm{O}$ interactions with the $\mathrm{O} \cdots \mathrm{O}$ distance ranging from 2.408 to $2.755 \AA$ (average: $2.612 \AA$ ) and the $\mathrm{O} \cdots \mathrm{O} \cdots \mathrm{O}$ angle ranging from $98.80^{\circ}$ to $133.00^{\circ}$ (average: $117.58^{\circ}$ ). These values are comparable to the values in ice $I_{h}$ [38]. The water molecules $\mathrm{O} 3 \mathrm{w}$ and $\mathrm{O} 4 \mathrm{w}$ on the $\mathrm{C} 2$ symmetry create $\mathrm{C} 4$ infinite chains, and the $\mathrm{O} 1 \mathrm{w}$ and $\mathrm{O} 2 \mathrm{w}$ are linked to $\mathrm{O} 3 \mathrm{w}$ and $\mathrm{O} 4 \mathrm{w}$ molecules, respectively, to form a "phenanthrene structure shape". There is a pair of independent water cluster polymers in compound 1. Each water layer is almost planar, with the largest atom deviation from the least squares plane of water cluster being $0.736 \AA$ for one and $0.747 \AA$ for the other, respectively (Supplementary Materials Figure S5). The dihedral angle between the two adjacent water cluster planes is $30.50^{\circ}$. The distances of the parallel water cluster plane are about $12.0 \AA$ (Supplementary Materials Figure S6). It should be noted that the isolated water cluster $\left[\left(\mathrm{H}_{2} \mathrm{O}\right)_{14}\right]_{n}$ forms a similar geometry configuration to that of "phenanthro-[1,2]phenanthrene polymer". Also, there are three longer bonds $(2.755,2.753$, and $2.742 \AA)$ and three shorter bonds $(2.408,2.410$, and $2.607 \AA)$ in the hexamer unit.

The two adjacent infinite water cluster polymers, $\left[\left(\mathrm{H}_{2} \mathrm{O}\right)_{14}\right]_{\mathrm{n}}$, are linked by a strong $\mathrm{O}-\mathrm{H} \cdots \mathrm{Cl}$ hydrogen bond [39]. The $\mathrm{Cl}$ atom in the $\left[\mathrm{CuCl}\right.$ (phen) $\left.\left(\mathrm{H}_{2} \mathrm{NCH}_{2} \mathrm{COO}\right)\right]$ group joins the two adjacent water clusters with the distance of $\mathrm{Cl} \cdots \mathrm{O} 1 \mathrm{w} 3.080 \AA$ and $\mathrm{Cl} \cdots \mathrm{O} 2 \mathrm{w} 3.223 \AA$, and the angle of $\mathrm{O} 1 \mathrm{w} \cdots \mathrm{Cl} \cdots \mathrm{O} 2 \mathrm{w} 48.85^{\circ}$, respectively (Figure 1, right). If we consider an extended motif, the four water molecules $(2 \mathrm{O} 1 \mathrm{w}, \mathrm{O} 2 \mathrm{w}, \mathrm{O} 3 \mathrm{w}$, and $\mathrm{O} 4 \mathrm{w})$ in the $\mathrm{T} 6(2) 6(2)$ water aggregate and chloride generates a cyclic motif T12(3). These water-chloride aggregate to join the two face-face parallel infinite water cluster polymers, forming a nanometer-sized water cluster conduit (Figure 2). The diameter of the 
water cluster conduit is about $12.0 \AA$. The strong hydrogen-bonding ability of the Ow $\cdots \mathrm{Cl}$ linker employed here plays a crucial role in promoting and stabilizing the aggregation of the water channel, thereby leading to the infinite nanometer-sized water cluster conduit in the crystal structure.

There are some intermolecular hydrogen bonds between the amino-group and carboxy group in $\left[\mathrm{CuCl}(\right.$ phen $\left.)\left(\mathrm{H}_{2} \mathrm{NCH}_{2} \mathrm{COO}\right)\right]$ and water clusters $\left[\left(\mathrm{H}_{2} \mathrm{O}\right)_{14}\right]_{\mathrm{n}}$. The donor and acceptor distances are

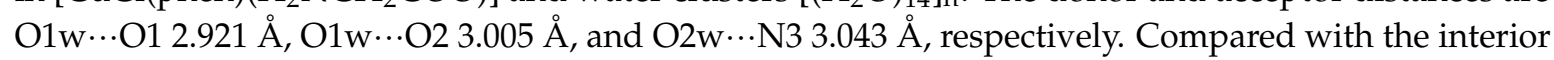
hydrogen bond in water cluster polymers, the exterior ones are easily separated, which reflects the relatively weak interactions. The hydrogen-bonding parameters give more evidence about the stability of water cluster polymers. The average Ow... Ow separation of $2.612 \AA$ in a water cluster polymer is

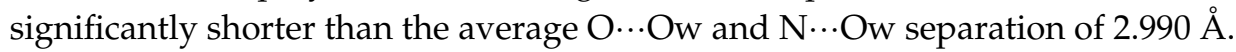

To gain more insight into the properties relative to water clusters, the dehydration behavior of compound (1) was investigated using thermogravimetric analysis. The TG and DTG curves of compound (1) are shown in Figure 3. The first step $\left(58{ }^{\circ} \mathrm{C}-80{ }^{\circ} \mathrm{C}\right)$ corresponds to the loss of one water molecule with the heat-absorption peaks (found $4.35 \%$ calc. $4.23 \%$ ). The second step, occurring between $160{ }^{\circ} \mathrm{C}$ and $260{ }^{\circ} \mathrm{C}$, corresponds to the loss of another water molecule (found $4.24 \%$ calc. $4.23 \%$ ). The third step, between $300{ }^{\circ} \mathrm{C}$ and $400{ }^{\circ} \mathrm{C}$, corresponds to the decomposition of the other two water molecules and the anion $\mathrm{H}_{2} \mathrm{NCH}_{2} \mathrm{COO}^{-}$. The residual compound is perhaps $\mathrm{CuCl}$ (phen)(HCOO) (found $14.84 \%$ calc. $14.34 \%$ ). Above $450{ }^{\circ} \mathrm{C}$, there are larger errors between the calculated values and the tested values, which, on the one hand, may be due to experimental error, and on the other hand, may be due to the decomposing debris of molecules.

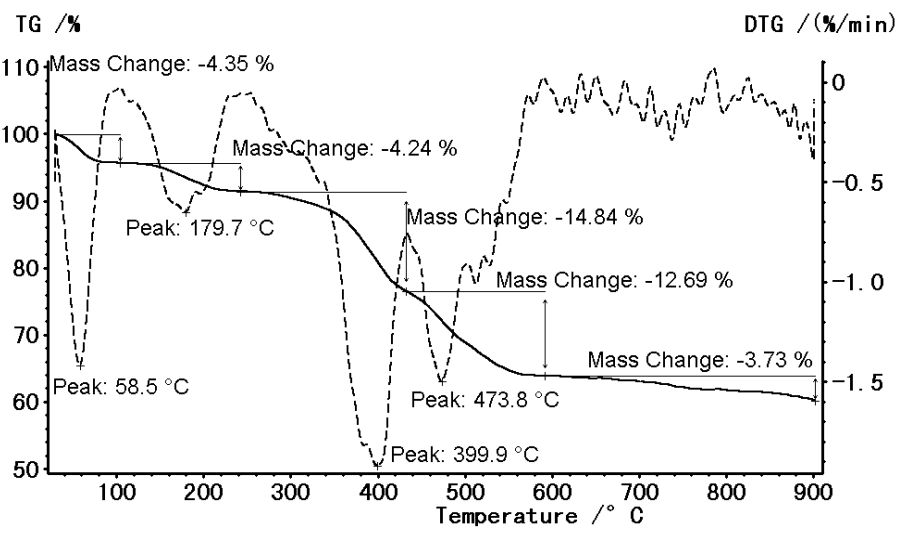

Figure 3. TG and DTG analysis for compound (1).

\section{Materials and Methods}

The $\mathrm{C}, \mathrm{H}$, and $\mathrm{N}$ elemental analyses were performed on a Perkin-Elmer elemental analyzer. Crystals data were collected on an Enraf-Nonius CAD-4 diffractometer with graphite monochromated Mo $K_{\alpha}$ radiation $(\lambda=0.71073 \AA)$. Intensities were corrected for Lorentz and polarization effects and empirical absorption, and data reduction was carried out. The structure was analyzed by the direct method. These data can be observed at the Cambridge Crystallographic Data Center via www.ccdc.cam.ac.uk/data-request/cif. The CCDC number is 644280.

A typical experimental procedure for compound (1) is below: Cupric chloride, sodium hydroxide, $\mathrm{H}_{2} \mathrm{NCH}_{2} \mathrm{COOH}$, phenanthroline, and other chemical reagents were obtained from commercial sources and used without further purification. To a 100-mL flask, $0.01 \mathrm{~mol}$ of $\mathrm{CuCl}_{2} \cdot 2 \mathrm{H}_{2} \mathrm{O}(1.70 \mathrm{~g}), 0.01 \mathrm{~mol}$ of $\mathrm{NaOH}(0.40 \mathrm{~g})$, and $0.01 \mathrm{~mol} \mathrm{H}_{2} \mathrm{NCH}_{2} \mathrm{COOH}(0.75 \mathrm{~g})$ in $40 \mathrm{~mL}$ of deionized water, as well as $0.20 \mathrm{~mol}$ ( $3.55 \mathrm{~g}$ ) of phenanthroline in $20 \mathrm{~mL}$ of ethanol was added while stirring at a temperature $80 \sim 90{ }^{\circ} \mathrm{C}$. The reaction was maintained for $4 \sim 5 \mathrm{~h}$ until the solution to clarification, following which the solution was filtered. After filtering out the precipitate, the resulting solution was allowed to stand at room temperature. Deep blue single crystals suitable for X-ray measurements were obtained over one week. 
From the element analysis below and the single crystal X-ray, we concluded that the compound (1) is [CuCl(phen) $\left.\left(\mathrm{H}_{2} \mathrm{NCH}_{2} \mathrm{COO}\right)\right] \cdot 4 \mathrm{H}_{2} \mathrm{O}$. Anal. Calc. for $\mathrm{C}_{40} \mathrm{H}_{56} \mathrm{Cl}_{2} \mathrm{Cu}_{2} \mathrm{~N}_{8} \mathrm{O}_{13}: \mathrm{C}, 39.50 \% ; \mathrm{H}, 4.70 \%$; , $9.87 \%, \mathrm{Cu} ; 14.93 \%, \mathrm{Cl}, 8.35 \%$; O, 22.57\%. Found: C, 39.32\%; H, 4.80\%; N, 9.68\%.

\section{Conclusions}

In summary, a water cluster conduit in $\left[\mathrm{CuCl}(\right.$ phen $\left.)\left(\mathrm{H}_{2} \mathrm{NCH}_{2} \mathrm{COO}\right)\right] \cdot 4 \mathrm{H}_{2} \mathrm{O}$ crystal was assembled. The water cluster aggregate mode, T6(2)6(2), and water-chloride extended aggregate mode, T12(3), have not been predicted theoretically nor previously reported experimentally. We also found that this structure of water cluster polymer was much like that of the phenanthro-[1,2]phenanthrene polymer in configuration. Water molecules, which have two hydrogen atoms and two lone pairs enabling them to participate in four hydrogen bonds in a tetrahedral arrangement, may be comparable with carbon $s p^{3}$ covalent chemistry, and form various geometry structures, similar to the carbon atom. This new structural data definitely enhances the understanding of the one-dimensional and two-dimensional structural aspects of water.

Supplementary Materials: The supplementary materials are available online.

Author Contributions: Fangfang Jian conceived and designed the experiments and wrote the paper; E Liu performed the experiments and analyzed the data; Jiao Xu contributed references; all authors read and approved the final manuscript.

Conflicts of Interest: The authors declare no conflict of interest.

\section{References}

1. Desiraju, G.R. Hydration in organic crystals: Prediction from molecular structure. J. Chem. Soc. Chem. Commun. 1991, 6, 426-428. [CrossRef]

2. Son, H.S.; Hong, B.H.; Lee, C.-W.; Yun, S.; Kim, K.S. A new type of helix pattern in polyalanine peptide. J. Am. Chem. Soc. 2001, 123, 514-515. [CrossRef] [PubMed]

3. Atwood, J.L.; Barbour, L.J.; Ness, T.J.; Raston, C.L.; Raston, P.L. A well-resolved ice-like $\left(\mathrm{H}_{2} \mathrm{O}\right)_{8}$ cluster in an organic supramolecular complex. J. Am. Chem. Soc. 2001, 123, 7192-7193. [CrossRef] [PubMed]

4. Doedens, R.J.; Yohannes, E.; Khan, M.I. Novel water clusters in the crystalline state: Structures of a symmetrical, cyclic hexamer and an 'opened-cube' octamer. Chem. Commun. 2002, 1, 62-63. [CrossRef]

5. Moorthy, J.N.; Natarajan, R.; Venugopalan, P. Characterization of a planar cyclic form of water hexamer in an organic supramolecular complex: An unusual self-assembly of bimesityl-3,3'-dicarboxylic acid. Angew. Chem. Int. Ed. 2002, 41, 3417-3420. [CrossRef]

6. Ghosh, S.K.; Bharadwaj, P.K. A dodecameric water cluster built around a cyclic quasiplanar hexameric core in an organic supramolecular complex of a cryptand. Angew. Chem. Int. Ed. 2004, 43, 3577-3580. [CrossRef] [PubMed]

7. Sun, D.; Xu, H.R.; Yang, C.F.; Wei, Z.H.; Zhang, N.; Huang, R.B.; Zheng, L.S. Encapsulated Diverse Water Aggregates in Two Ag(l)/4,4'-Bicarboxylate Hosts: 1D Water Tape and Chain. Cryst. Growth Des. 2010, 10, 4642-4649. [CrossRef]

8. Luo, G.G.; Xiong, H.B.; Dai, J.C. Syntheses, Structural Characterization, and Properties of $\left\{\left[\mathrm{Cu}(\mathrm{bPP})_{2}\left(\mathrm{H}_{2} \mathrm{O}\right)_{2}\right](\mathrm{tp})\right.$ center dot $\left.7 \mathrm{H}_{2} \mathrm{O}\right\}$ and $\left\{\left[\mathrm{Cu}(\mathrm{bPP})_{2}\left(\mathrm{H}_{2} \mathrm{O}\right)\right](\mathrm{ip})\right.$ center dot $\left.7 \mathrm{H}_{2} \mathrm{O}\right\}$ Complexes. New Examples of the ORGANIC anionic Template Effect on Induced Assembly of Water Clusters (bpp=1,3Bis(4-pyridyl)propane,tp=Terephthalate,ip=isophthalate). Cryst. Growth Des. 2011, 11, 507-515.

9. Luo, G.G.; Xiong, H.B.; Sun, D.; Wu, D.L.; Huang, R.B.; Dai, J.C. A Discrete spirocyclic (H2O)(9) Cluster and 1D Novel Water with Chain Tetrameric and Octameric Clusters in Cationic Hosts. Cryst. Growth Des. 2011, 11, 1948-1956. [CrossRef]

10. Luo, G.G.; Wu, D.L.; Wu, J.H.; Xia, J.X.; Liu, L.; Dai, J.C. Direct observation of conformational change of adipate dianions encapsulated in water clusters. CrystEngComm 2012, 14, 5377-5380. [CrossRef]

11. Buck, U.; Huisken, F. Infrared Spectroscopy of Size-Selected Water and Methanol Clusters. Chem. Rev. 2000, 100, 3863-3890. [CrossRef] [PubMed] 
12. Head-Gordon, T.; Hura, G. Water structure from scattering experiments and simulation. Chem. Rev. 2002, 102, 2651-2669. [CrossRef] [PubMed]

13. Das, M.C.; Maity, S.B.; Bharadwaj, P.K. Supramolecular association of water molecules forming discrete clusters in the voids of coordination polymers. Curr. Opin. Solid State Mater. Sci. 2009, 13, 76-90. [CrossRef]

14. Zuhayra, M.; Kampen, W.U.; Henze, E.; Soti, Z.; Zsolnai, L.; Huttner, G.; Oberdorfer, F. A planar water tetramer with tetrahedrally coordinated water embedded in a hydrogen bonding network of $\left[\mathrm{Tc}_{4}(\mathrm{CO})_{12}-\left(\mathrm{mu}^{3}-\mathrm{OH}\right)_{4} \cdot 4 \mathrm{H}_{2} \mathrm{O}\right]$. J. Am. Chem. Soc. 2006, 128, 424-425. [CrossRef] [PubMed]

15. Long, L.-S.; Wu, Y.-R.; Huang, R.-B.; Zheng, L.-S. A well-resolved uudd cyclic water tetramer in the crystal host of [Cu(adipate)(4,4-bipyridine)] $\left(\mathrm{H}_{2} \mathrm{O}\right)_{2}$. Inorg. Chem. 2004, 43, 3798-3800. [CrossRef] [PubMed]

16. Pal, S.; Sankaran, N.B.; Samanta, A. Structure of a self-assembled chain of water molecules in a crystal host. Angew. Chem. Int. Ed. 2003, 42, 1741-1743. [CrossRef] [PubMed]

17. Saha, B.K.; Nangia, A. First example of an ice-like water hexamer boat tape structure in a supramolecular organic host. Chem. Commun. 2006, 1825-1827. [CrossRef] [PubMed]

18. Custelcean, R.; Afloroaei, C.; Vlassa, M.; Polverejan, M. Formation of Extended Tapes of Cyclic Water Hexamers in an Organic Molecular Crystal Host. Angew. Chem. Int. Ed. 2000, 39, 3094-3096. [CrossRef]

19. Ye, B.-H.; Ding, B.-B.; Weng, Y.-Q.; Chen, X.-M. Formation of one-dimensional metal-water chain containing cyclic water hexamers. Inorg. Chem. 2004, 43, 6866-6868. [CrossRef] [PubMed]

20. Bharadwaj, P.K. Coexistence of Water Dimer and Hexamer Clusters in 3D Metal-Organic Framework Structures of Ce(III) and Pr(III) with Pyridine-2,6-dicarboxylic Acid. Inorg. Chem. 2003, 42, 8250-8254.

21. Mukhopadhyay, U.; Bernal, I. Self-Assembled Hexameric Water Clusters Stabilized by a Cyano-Bridged Trimetallic Complex. Cryst. Growth Des. 2005, 5, 1687-1689. [CrossRef]

22. Tadokoro, M.; Fukui, S.; Kitajima, T.; Nagao, Y.; Ishimaru, S.; Kitagawa, H.; Isobe, K.; Nakasuji, K. Structures and phase transition of multi-layered water nanotube confined to nanochannels. Chem. Commun. 2006, 1274-1276. [CrossRef] [PubMed]

23. Ma, B.-Q.; Sun, H.-L.; Gao, S. Observation of an octameric water cluster containing a book-shaped hexamer in a 4f-3d complex. Chem. Commun. 2005, 2336-2338. [CrossRef] [PubMed]

24. Liao, Y.-C.; Jiang, Y.-C.; Wang, S.-L. Discrete water hexamers and template-assisted molecular recongnition in an elastic zincophosphate lattice. J. Am. Chem. Soc. 2005, 127, 12794-12795. [CrossRef] [PubMed]

25. Keutsch, F.N.; Cruzan, J.D.; Saykally, R.J. The Water Trimer. Chem. Rev. 2003, 103, 2533-2578. [CrossRef] [PubMed]

26. Carballo, R.; Covelo, B.; Lodeiro, C.; Vazquez-Lopez, E.M. One-dimensional fluorescent stacking structure based on zinc mixed-complex salt encapsulated within an 'ice-like' three-dimensional hydrogen-bonded water network. CrystEngComm 2005, 7, 294-296. [CrossRef]

27. Sreenivasulu, B.; Vittal, J.J. Helix inside a Helix: Encapsulation of Hydrogen-Bonded Water Molecules in a Staircase Coordination Polymer. Angew. Chem. Int. Ed. 2004, 43, 5769-5772. [CrossRef] [PubMed]

28. Kim, H.-J.; Jo, H.J.; Kim, J.; Kim, S.-Y.; Kim, D.; Kim, K. Supramolecular self-assembly of tin(IV) porphyrin channels stabilizing single-file chains of water molecules. CrystEngComm 2005, 7, 417-420. [CrossRef]

29. Cheruzel, L.E.; Pometun, M.S.; Cecil, M.R.; Mashuta, M.S.; Wittebort, R.J.; Buchanan, R.M. Structures and Solid-State Dynamics of One-Dimensional Water Chains Stabilized by Imidazole Channels. Angew. Chem. Int. Ed. 2003, 42, 5452-5455. [CrossRef] [PubMed]

30. Mukherjee, A.; Saha, M.K.; Nethaji, M.; Chakravarty, A.R. Helical supramolecular host with aquapores anchoring alternate molecules of helical water chains. Chem. Commun. 2004, 716-717. [CrossRef] [PubMed]

31. Neogi, S.; Bharadwaj, P.K. An Infinite Water Chain Passes through an Array of Zn(II) Metallocycles Built with a Podand Bearing Terminal Carboxylates. Inorg. Chem. 2005, 44, 816-818. [CrossRef] [PubMed]

32. Liu, Q.-Y.; $\mathrm{Xu}, \mathrm{L} .\left(\mathrm{H}_{2} \mathrm{O}\right)_{12}$-containing infinite chain encapsulated in supramolecular open framework built of cadmium(II), 1,3-di(4-pyridyl)propane and 5-sulfoisophthalic acid monosodium salt. CrystEngComm 2005, 7, 87-89. [CrossRef]

33. Assaf, K.I.; Ural, M.S.; Pan, F.F.; Georgiev, T.; Simova, S.; Rissanen, K.; Gabel, D.; Nau, W.M. Water Structure Recovery in Chaotropic Anion Recognition: High-Affinity Binding of Dodecaborate Clusters to $\gamma$-Cyclodextrin. Angew. Chem. Int. Ed. 2015, 54, 6956-6960. [CrossRef]

34. Neogi, S.; Savitha, G.; Bharadwaj, P.K. Structure of Discrete $\left(\mathrm{H}_{2} \mathrm{O}\right)_{12}$ Clusters Present in the Cavity of Polymeric Interlinked Metallocycles of $\mathrm{Nd}(\mathrm{III})$ or $\mathrm{Gd}(\mathrm{III})$ and a Podand Ligand. Inorg. Chem. 2004, 43, 3771-3773. [CrossRef] [PubMed] 
35. Infantes, L.; Chisholm, J.; Motherwell, S. Extended motifs from water and chemical functional groups in organic molecular crystals. CrystEngComm 2003, 5, 480-486. [CrossRef]

36. Infantes, L.; Motherwell, S. Water clusters in organic molecular crystals. CrystEngComm 2002, 4, 454-461. [CrossRef]

37. Mascal, M.; Infantes, L.; Chisholm, J. Water Oligomers in Crystal Hydrates-What's News and What Isn't? Angew. Chem. Int. Ed. 2006, 45, 32-36. [CrossRef] [PubMed]

38. Eisenberg, D.; Kauzmann, W. The Structure and Properties of Water; Oxford University Press: New York, NY, USA, 1969.

39. Banerjee, S.; Murugavel, R. Formation of One-Dimensional Water Inside an Organic Solid: Supramolecular Architectures Derived by the Interaction of Aminobenzoic Acids with Nitrogen Bases and $\mathrm{H}_{2} \mathrm{SO}_{4}$. Cryst. Growth Des. 2004, 4, 545-552. [CrossRef]

Sample Availability: Samples of the compound $\left[\mathrm{CuCl}(\mathrm{phen})\left(\mathrm{H}_{2} \mathrm{NCH}_{2} \mathrm{COO}\right)\right] \cdot 4 \mathrm{H}_{2} \mathrm{O}$ are available from the authors.

(C) 2017 by the authors. Licensee MDPI, Basel, Switzerland. This article is an open access article distributed under the terms and conditions of the Creative Commons Attribution (CC BY) license (http://creativecommons.org/licenses/by/4.0/). 